\title{
Factors Influencing the Soil-Water Characteristics of Unsaturated Tropical Silty Sand
}

\author{
B. D. Oluyemi-Ayibiowu, T. O. Akinleye \\ Department of Civil Engineering, The Federal University of Technology, Akure, Nigeria \\ Email: bayibiowu@yahoo.com
}

How to cite this paper: Oluyemi-Ayibiowu, B. D., \& Akinleye, T. O. (2019). Factors Influencing the Soil-Water Characteristics of Unsaturated Tropical Silty Sand. Journal of Geoscience and Environment Protection, 7, 264-273.

https://doi.org/10.4236/gep.2019.75019

Received: March 16, 2019

Accepted: May 27, 2019

Published: May 30, 2019

Copyright $\odot 2019$ by author(s) and Scientific Research Publishing Inc. This work is licensed under the Creative Commons Attribution International License (CC BY 4.0).

http://creativecommons.org/licenses/by/4.0/

(c) (i) Open Access

\begin{abstract}
Fine grain soils have a complex engineering behaviour which depends but not limited to moisture content, changes in external pressure and characteristics of the pore medium. Sand often contains a considerable percent of silt which is expected to alter its natural behaviour. This composite matrix is referred to as silty-sand. To understand the behaviour of this matrix under varying moisture conditions, some of the factors influencing the soil-water characteristics of unsaturated silty sands were investigated. Representative samples were collected from a river bank after its index properties were predetermined in the laboratory. The samples were compacted at different moisture conditions and compactive efforts. With the pressure plate extractor device, the Soil-Water Characteristic (SWC) was obtained and SWC Curves plotted. Compaction at greater compactive effort (modified proctor) and optimum moisture content produced the largest air entry value and reduced air voids. The air entry values of the soils obtained ranged from $21 \mathrm{kPa}$ to $57 \mathrm{kPa}$. Also changes in the shape of the SWCC were consistent with changes in pore size which occur by varying compaction conditions. Result shows that soil structure, compaction water content, compactive effort and percentage of fine particles are factors affecting the Soil-Water Characteristics.
\end{abstract}

\section{Keywords}

Soil-Water Characteristics, Soil-Water Characteristics Curve, Tropical Silty Sand Soil, Compaction Water Content, Compactive Efforts

\section{Introduction}

Silty sand is considered a delicate composite matrix containing a sand-grain-matrix and a silt-matrix. Soils in unsaturated state according to Fredlund and Morgens- 
tern (1977) are said to consist of a four-phase system: soil particles, pore air, pore water and a contractile skin. These soils are found most especially in the arid and semi arid regions where the ground water table is at a considerably great depth beneath the ground surface, such as the tropical regions. Natural, desiccated and compacted soils are few examples that fall into this category. They are known to possess negative pore water pressures and are susceptible to expansion and shrinkage. Compacted natural soils used as hydraulic barriers in waste containment facilities such as engineered landfills are often unsaturated and modelling of flow and transport through these soils requires the knowledge of their unsaturated hydraulic properties.

The measure of the water holding capacity of soils as the water content changes when subjected to various degree of suction is termed soil-water characteristics. Evaporation can induce high soil suctions near the ground surface. On the other hand, precipitation can eliminate the soil suction. Due to the hysteretic effect of water filling and draining from the pores, different wetting and drying soil-water characteristics curves may be distinguished. Tinjum et al. (1997) defined Soil-Water Characteristics Curve (SWCC) as the relationship between matric suction $(\Psi)$ (i.e. difference in the pore air pressure and pore water pressure) and water content (gravimetric $(\mathrm{w})$ or volumetric $(\theta)$ or degree of saturation (S)) of any soil. It has repeatedly been identified as the key soil information required for the analysis of seepage, strength characteristics, permeability coefficient, water storage capacity and volume change problems involving unsaturated soils (Barbour, 1998; Fredlund, 2000; Han et al., 2016).

Previous studies on the soil-water characteristics of fine grained soils in the tropical region mainly inspected the response of clean sands. However, field observations in this region show that most times, sand doesn't exist naturally in its pure state. It may contain a considerable amount of silt and/or clay. Therefore, these fines are being expected to influence the engineering behaviour of the soil matrix. This study therefore investigates the factors that influence the soil-water behaviour and responses of a sand-silt matrix under varying magnitude of suction and load conditions (compaction).

\section{Materials and Methods}

Tropical silty sand soils examined in this study were collected at Igbatoro area, Akure North Local Government Area of Ondo State. Samples were collected using the method of disturbed sampling and were obtained at a depth of about 1 meter below the ground level. $100 \mathrm{~kg}$ of the sample after collection was crushed into smaller pieces and oven dried in the laboratory. The index and geotechnical properties were determined. These included; grain size distribution, specific gravity, hydrometer, compaction, Atterberg limits, mineralogical analysis, soil structure and soil-water characteristics analysis.

SWC analysis was achieved using the pressure plate extractor which makes use of the axis translation technique in varying the pore air and pore water 
pressure. The pressure plate extractor makes use of the direct method of measuring the pore water pressure in the soil or imposed air pressure. The weighing soil method (WSM) was adopted in this study, which measures the water content by weighing the soil sample when equilibrium is reached. The mineralogical composition of the soil was obtained using the X-ray diffractometer while soil structure was obtained with the aid of a scanning electron microscope.

For the study, testing was in accordance with BS 1377: 1990 (Soil for Civil Engineering Purposes). Specimens for compaction tests were prepared by mixing the relevant quantity of dry samples previously crushed to pass through BS sieve No.4 and $4.76 \mathrm{~mm}$ aperture with water. They water content were in the range $5.5 \%$ to $25.5 \%$ and at four different compactive efforts. At each point, the optimum moisture content and maximum dry density were determined.

The soil specimens after preparation were compacted using four compactive efforts which are reduced proctor, standard proctor, West African standard and modified proctor at $-2,0$ and +2 from dry to the wet side of the line of OMC. 2.5 $\mathrm{kg}$ of each specimen was moistened with tap water, mixed thoroughly and compacted in BS moulds and then cored into stainless steel rings with inside diameters of $50 \mathrm{~mm}$ and height $50 \mathrm{~mm}$ with the aid of a mallet. The cored samples in the stainless rings were tightly covered at both ends to retain its properties prior to testing with the pressure extractor equipment. The soil specimen was placed on the high air-entry ceramic disk inside the retaining cylinder. The air-entry ceramic disk and soil were first saturated. In the drying test, each batch of sample was subjected to full saturation by capillary action for a period of three (3) weeks after which excess water was removed from the cell. The cell cover was then mounted and tightened into place and air pressure was applied to the soil specimen in series of increments to achieve different matric suction $(\Psi)$. Each increment in air pressure caused water to be expelled from the specimen until an equilibrium state is reached for the matric suction that has been established.

The entire pressure application for each batch lasted about two (2) weeks, while the entire process from specimen preparation, saturation and pressure application lasted about three (3) months. Pressure was applied using regulated compressed air from a compressor. The soils were subjected to pressures of 10 , $30,100,500,1000$ and $1500 \mathrm{kPa}$, respectively. On completion of the test, the equipment was disassembled, the soil specimen removed and placed in an oven to determine its final gravimetric water content.

\section{Results and Discussion}

\subsection{Geotechnical Properties of Soil}

The specific gravity of the soil sample was found to be 2.52. Atterberg limits of the soil show that it exhibits low plasticity as indicated by the plasticity index of 9\% with Liquid Limit of $48 \%$ and Plastic Limit of 39\%. The particle size distribution curve of the soils (Figure 1) indicated that the soil contains about $15.22 \%$ gravelly material, $24.53 \%$ medium size/coarse material and $60.25 \%$ fine grained 
PARTICLE SIZE DISTRIBUTION CURVE

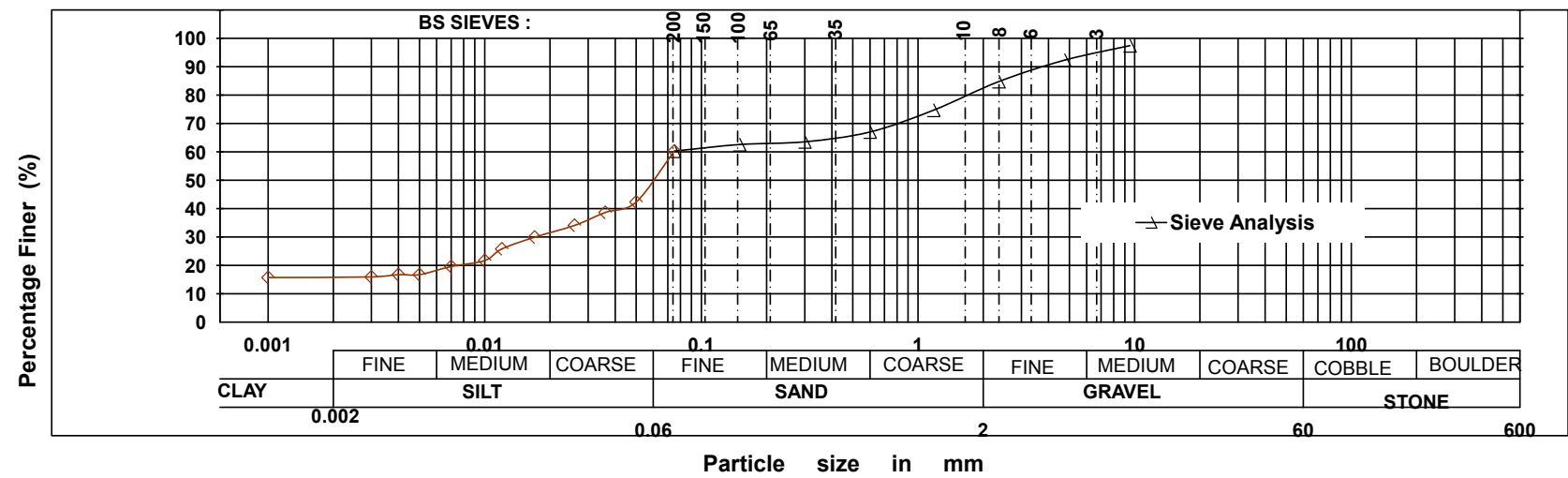

Figure 1. Particle Size Distribution Curve of the tested soil.

material. According to AASHTO classification system, the soil is classified as A-5 material, while Unified soil classification system (USCS) classifies the soil as OL. On the basis of Casangrande plasticity chart, these soils are Organic silts and organic silty clays of low plasticity. Summary of the index properties of the soil is presented in Table 1.

The soil sample was observed to comprise of two minerals; rock forming mineral Quartz dominant in the soil with $67 \%$ and non-expansive clay mineral Kaolinite with $33 \%$. Structure of each of the soil was invested using the scanning electron microscope. The soil sample was observed to have rotund shape particles. Results showed that the soil sample has dispersed particles having both the macro and micro structure present.

The summary of the compaction characteristics are shown in Table 2. The modified proctor produced the highest maximum dry densities for all soil tested $\left(1.89 \mathrm{Mg} / \mathrm{m}^{3}\right)$ at corresponding lowest optimum moisture content of $12.40 \%$. It can be inferred that maximum dry densities of the soils were influenced slightly with the compactive energy utilized, the number of blows and the falling height of rammer.

\subsection{Effect of Compaction Molding Water Content on Soil}

The soil-water characteristics curves Figures 2 to 5 show the effect of molding water content on specimen using the different compactive efforts. Similar trend was observed in all compactive efforts used. The shape of soil water characteristics curve is affected by the compaction molding water content. The optimum specimens show a higher resistance to water discharge compared to the wet of optimum and dry of optimum specimen. The dry of optimum specimen showed the lowest resistance to water discharge. This is due to the structure of the soil at compaction. Soils generally have two levels of structures at varying degree; a macro-level and micro-level structure. The soil micro structure is described as the elementary particle associations within the soil, while the arrangement of the soil aggregates is referred to as the macrostructure (Mitchell, 1976). When soils 
Table 1. Index properties of soil.

\begin{tabular}{cc}
\hline Properties & Result \\
\hline Specific Gravity & 2.52 \\
Liquid Limit, \% & 48 \\
Plastic Limit, \% & 39 \\
Plasticity Index, \% & 9 \\
\% Passing BS No. 4 sieve & 92.30 \\
\% Passing BS No. 10 sieve & 84.78 \\
\% Passing BS No. 40 sieve & 63.07 \\
\% Passing BS No. 200 sieve & 60.25 \\
AASHTO classification & A-5 \\
USCS classification & OL \\
Group index & 6 \\
\hline
\end{tabular}

Table 2. Compaction characteristics of soil samples.

\begin{tabular}{ccc}
\hline & \multicolumn{2}{c}{ Soil Sample } \\
\cline { 2 - 3 } Compactive Efforts & Maximum dry density, $\left(\mathrm{Mg} / \mathrm{m}^{3}\right)$ & Optimum moisture content, (\%) \\
\hline Reduced Proctor & 1.00 & 15.20 \\
Standard Proctor & 1.68 & 12.58 \\
West African Standard & 1.49 & 13.41 \\
Modified Proctor & 1.89 & 12.40 \\
\hline
\end{tabular}

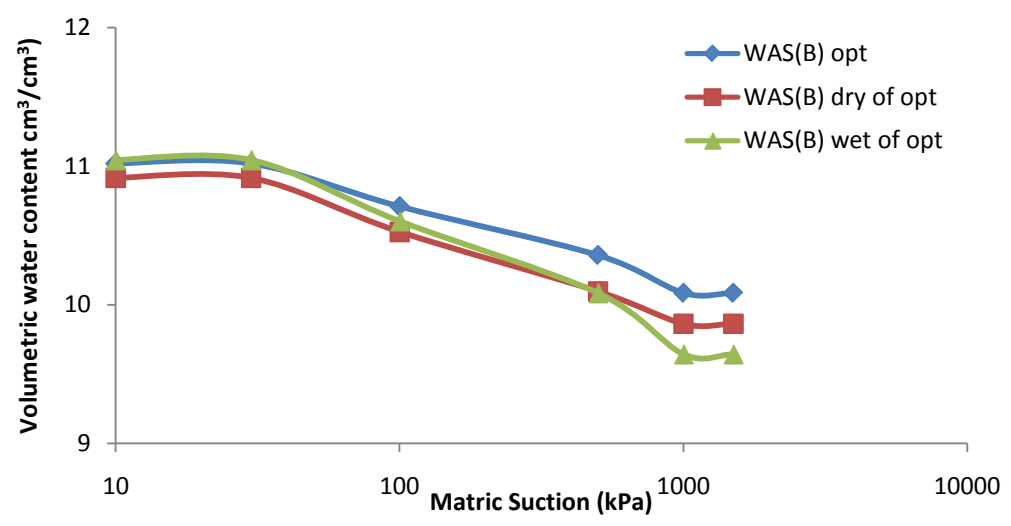

Figure 2. Variation of soil-water characteristics with matric suction for Soil Sample using WAS compactive effort at different molding water contents.

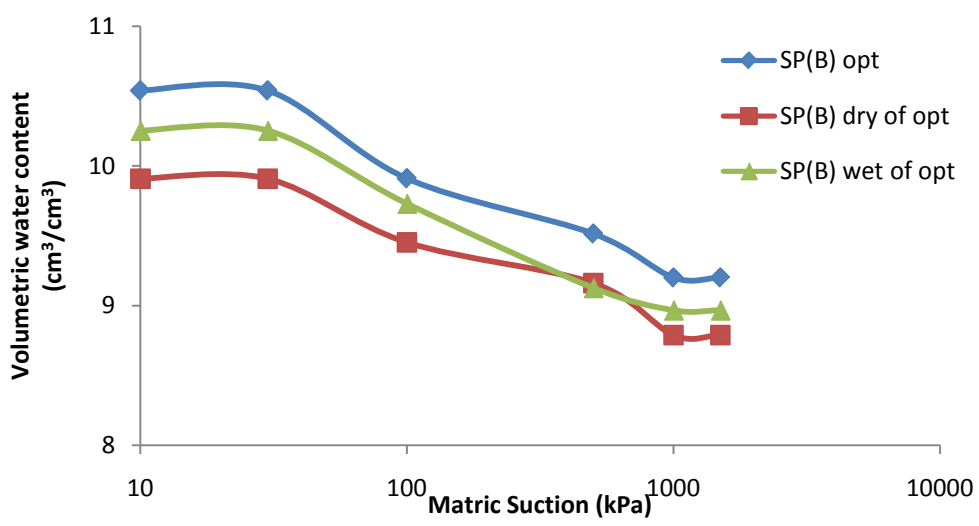

Figure 3. Variation of soil-water characteristics with matric suction for Soil Sample using standard proctor compactive effort at different molding water contents. 


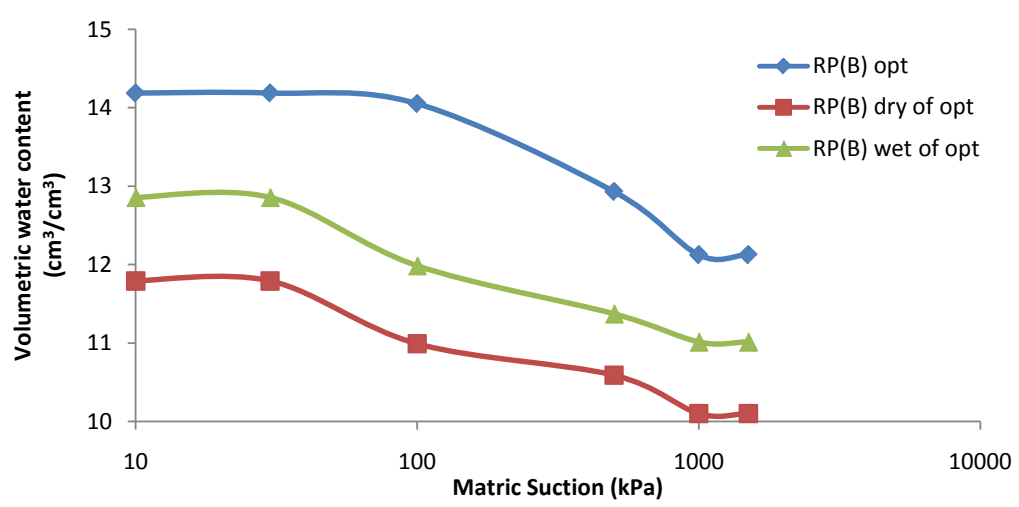

Figure 4. Variation of soil-water characteristics with matric suction for Soil Sample using reduced proctor compactive effort at different molding water contents.

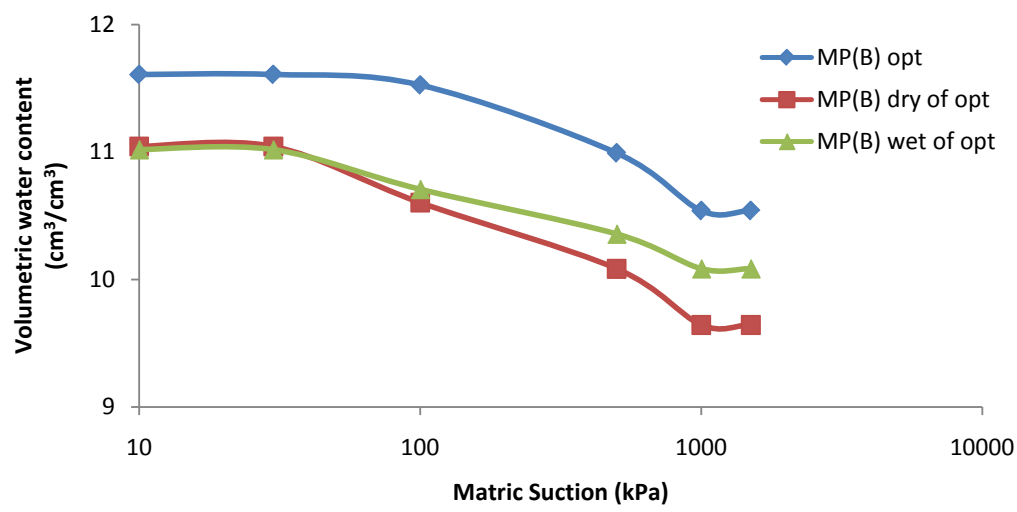

Figure 5. Variation of soil-water characteristics with matric suction for Soil Sample using modified proctor compactive effort at different molding water contents.

are compacted at different molding water contents at the same compactive efforts, the resulting macro-structure is different.

The dry of optimum compacted samples have bimodal pore-size distribution, with relatively lager pores which are located between the clods of the soil which were not remoulded during compaction. Relatively low suction values were required to remove water from these larger pores. Compaction of soil at dry of optimum results in flocculated soil fabric structure while those compacted wet of optimum have fabrics that are more oriented or dispersed for a given compactive effort. This is in agreement with result obtained by Holtz and Kovacs (1981). A soil compacted at the same water content (dry of optimum, optimum or wet of optimum) but with higher compactive effort will be more oriented than that compacted at a lower compactive effort.

According to Diamond (1971), soil compacted at a given effort will have greatest pore size at dry of optimum, followed by that compacted wet of optimum and then least pore size when compacted at optimum water content. Also, pore size reduces when a soil is compacted at the same water content but with higher compactive effort. This trend was observed in the results obtained in this study. It then follows that at nearly all the compactive effort and for matric suction values of $1500 \mathrm{kPa}$, specimens of soils compacted dry of optimum have the 
least water contents. This is because of the large pores due to the randomness in particle arrangement.

Also, samples compacted wet of optimum were observed to have broad unimodial pore-size distributions, primarily containing micro scale pores. The pore spaces are not generally interconnected; the increasing water content helped in deflocculating the particle structure thus, reducing the voids. These soils have higher water storage capacity due to their structure. They have no visible inter-clod pores and offer more resistances to de-saturation under an applied suction in comparison to specimen compacted dry of optimum. Hence, the micro structure controls and assists the de-saturation characteristics of the soil. Samples compacted at optimum fall between both, since the boundary between the closed pore and open pore conditions occurs at water contents approximately equal to the optimum water content. Results obtained are similar to those observed by Garcia-Bengochea et al. (1979), Acar and Oliveri (1990), Vanapalli et al. (1999), Tinjum et al. (1997) and Nwaiwu (2004).

\subsection{Effect of Compactive Effort}

Generally, for each of the samples, SWCCs of specimens prepared at higher compactive efforts was observed to plot below those prepared at lower compactive efforts. They were observed to contain smaller amount of water in their pores as against those prepared at lower compactive efforts while applying same suction. This trend is in line with the results reported by Tinjum et al. (1997), Miller et al. (2002), Osinubi and Bello (2011). Soils compacted with higher compaction energies have smaller pores (air voids) as a result of increase densification of the soil. As the compactive effort increases, the optimum moisture content reduces leading to small amount of water being contained in the specimen at the same water content as those of lower compaction energy. The effect of compactive effort on soil-water characteristics curve (SWCC) for each of the samples compacted at optimum, wet of optimum and dry of optimum water contents is shown in Figures 6 to 8.

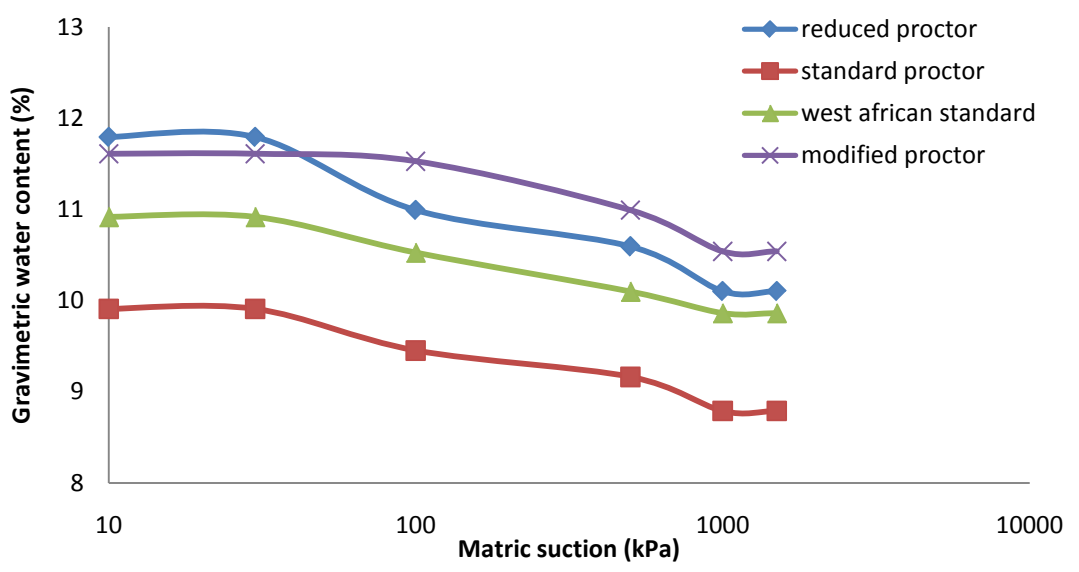

Figure 6. Variation of soil-water characteristics with matric suction at optimum moisture content for Soil Sample at different compactive efforts. 


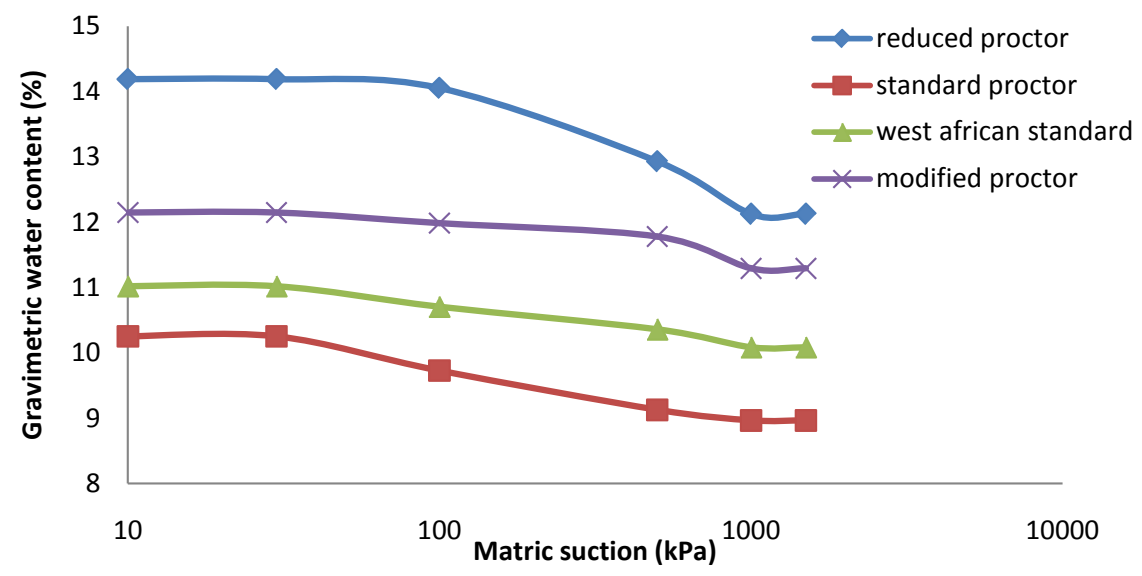

Figure 7. Variation of soil-water characteristics with matric suction at wet of optimum moisture content for Soil Sample at different compactive efforts.

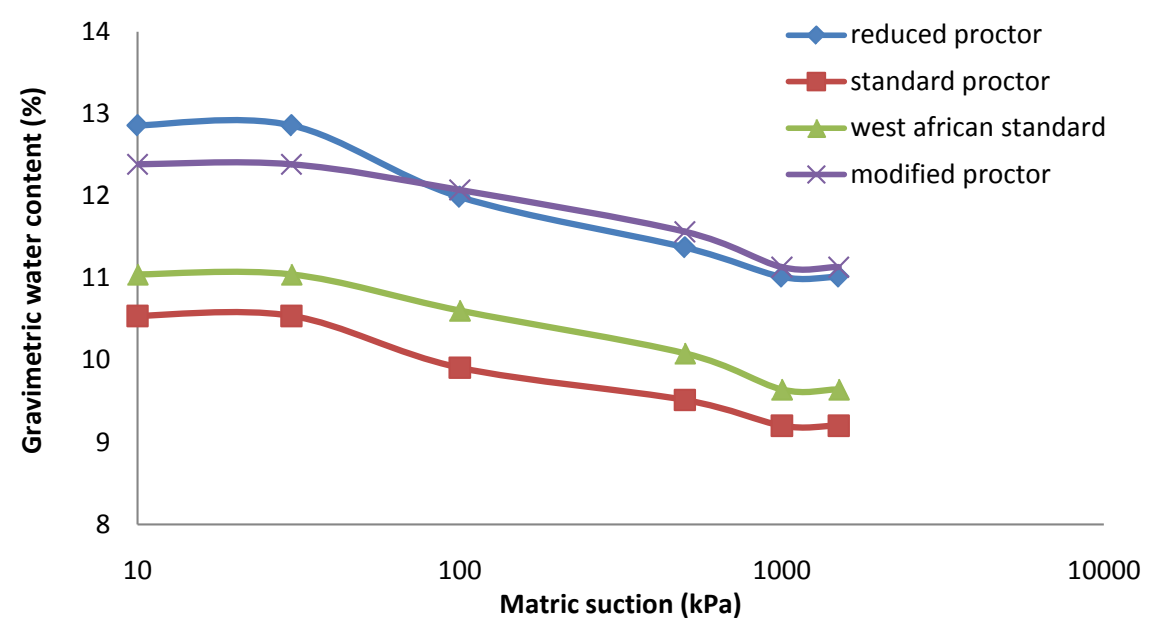

Figure 8. Variation of soil-water characteristics with matric suction at dry of optimum moisture content for Soil Sample at different compactive efforts.

\subsection{Air-Entry (A.E) and Residual Suction (R.S) Results}

The curves obtained from experimental study are in conformity with that obtained for reddish tropical soils by Osinubi and Bello (2011). The air entry values (A.E.V) obtained ranged from $21 \mathrm{kPa}$ to $57 \mathrm{kPa}$ while residual suction ranged from 800 to $1010 \mathrm{kPa}$. Specimens compacted at optimum moisture content and higher compactive efforts were observed to have higher Air-Entry and least residual suction values. Results of the A.E and R.S obtained are presented in Table 3.

\section{Conclusion}

Matric suction decreases with an increase in water content of tropical silty sand soils. At matric suction of $1500 \mathrm{kPa}$ (High suction range), the soil samples contained certain degree of moisture. Thus, it can be inferred that most in-situ tropical silty sand soil exists mostly in an unsaturated state. The dry of optimum specimens exhibits a steeper soil-water characteristics curve when compared with specimens compacted at optimum and wet of optimum water contents. The 
Table 3. Air-entry and residual suction values.

\begin{tabular}{ccccccccccc}
\hline \multirow{2}{*}{ Soil Type } & Moisture & \multicolumn{2}{c}{ WAS } & \multicolumn{2}{c}{ SP } & \multicolumn{2}{c}{ RP } & \multicolumn{2}{c}{ MP } \\
\cline { 2 - 10 } & Condition & $\begin{array}{c}\text { A.E.V } \\
(\mathrm{kPa})\end{array}$ & $\begin{array}{c}\text { R.S } \\
(\mathrm{kPa})\end{array}$ & $\begin{array}{c}\text { A.E.V } \\
(\mathrm{kPa})\end{array}$ & $\begin{array}{c}\text { R.S } \\
(\mathrm{kPa})\end{array}$ & $\begin{array}{c}\text { A.E.V } \\
(\mathrm{kPa})\end{array}$ & $\begin{array}{c}\text { R.S } \\
(\mathrm{kPa})\end{array}$ & $\begin{array}{c}\text { A.E.V } \\
(\mathrm{kPa})\end{array}$ & $\begin{array}{c}\text { R.S } \\
(\mathrm{kPa})\end{array}$ \\
\hline \multirow{3}{*}{$\begin{array}{c}\text { Silty } \\
\text { Sand }\end{array}$} & Opt. & 32 & 900 & 40 & 900 & 22 & 950 & 57 & 1000 \\
& Dry of Opt. & 31 & 800 & 32 & 950 & 21 & 1010 & 32 & 880 \\
& Wet of Opt. & 30 & 1010 & 34 & 800 & 22 & 1010 & 35 & 950 \\
\hline
\end{tabular}

dry of optimum specimen's act is more like a coarse grained soil with a highly aggregated macro structure. The soil structure was influenced considerably by the initial molding water content. Specimen compacted dry of optimum had the highest pore size distribution. Air-entry value was observed to be affected more by the arrangement of compacted soil and not solely on the percentage of fine particles. From experiment result, soil-water characteristics curve can be said to be dependent mainly on the compaction and molding water content of the soil.

\section{Conflicts of Interest}

The authors declare no conflicts of interest regarding the publication of this paper.

\section{References}

Acar, Y. B., \& Oliveri, I. (1990). Pore Fluids Effects on the Fabric and Hydraulic Conductivity of Laboratory-Compacted Clay. Transportation Research Record, No. 1219, 144-159.

Barbour, S. L. (1998). Nineteenth Canadian Geotechnical Colloquium: The Soil-Water Characteristics Curve: A Historical Perspective. Canadian Geotechnical Journal, 35, 873-894. https://doi.org/10.1139/t98-040

Diamond, S. (1971). Microstructure and Pore Structure of Impact-Compacted Clays. Clays and Clay Mineral, 19, 239-249. https://doi.org/10.1346/CCMN.1971.0190405

Fredlund, D. G. (2000). The Implementation of Unsaturated Soil Mechanics into Geotechnical Engineering. Canadian Geotechnical Journal, 37, 963-986. https://doi.org/10.1139/t00-026

Fredlund, D. G., \& Morgenstern, N. R. (1977). Stress State Variables for Unsaturated Soils. Journal of Geotechnical Engineering, 103, 447-466.

Garcia-Bengochea, I., Lovell, C., \& Altschaeffl, A. (1979). Pore-Distribution and Permeability of Silty Clays. Journal of Geotechnical Engineering Division, 105, 839-856.

Han, Z., \& Vanapalli, S. K. (2016). Stiffness and Shear Strength of Unsaturated Soils in Relation to Soil-Water Characteristic Curve. Géotechnique, 66, 627-647. https://doi.org/10.1680/jgeot.15.P.104

Holtz, R. D., \& Kovacs, W. D. (1981). An Introduction to Geotechnical Engineering (733 p.). Eaglewood Cliff, NJ: Prentice-Hall, Inc.

Miller, C. J., Yesiller, N., Yaldo, K., \& Merayyan, S. (2002). Impact of Soil Type and Compaction Conditions on Soil Water Characteristics. Journal of Geotechnical and Geoenvironmental Engineering, 128, 733-742. 
https://doi.org/10.1061/(ASCE)1090-0241(2002)128:9(733)

Mitchell, J. K. (1976). Fundamental of Soil Behavior (422 pp.). New York: John Wiley and Sons, Inc.

Nwaiwu, C. M. O. (2004). Evaluation of Compacted Lateritic Soils as Hydraulic Barriers in Municipal Solid Waste Containment Systems. Unpublished Ph.D. Thesis, Zaria, Nigeria: Ahmadu Bello University.

Osinubi, K. J., \& Bello, A. A. (2011). Soil-Water Characteristics Curves for Reddish Brown Tropical Soil. Electronic Journal of Geotechnical Engineering, 16, 1-25.

Tinjum, J. M., Benson. C. H., \& Blotz, L. R. (1997). Soil Water Characteristics Curves for Compacted Clays. Journals of Geotechnical and Geoenvironmental Engineering, 123, 1060-1069. https://doi.org/10.1061/(ASCE)1090-0241(1997)123:11(1060)

Vanapalli, S. K., Fredlund, D. G., \& Pufahi, D. E. (1999). The Influence of Soil Structure and Stress History on the Soil-Water Characteristics of a Compacted Till. Géotechnique, 49, 143-159. https://doi.org/10.1680/geot.1999.49.2.143 